\title{
A DIÁKOK ISKOLÁBA JÁRÁSI SZOKÁSAINAK VIZSGÁLATA BUDAPEST KELETI AGGLOMERÁCIÓJÁBAN
}

INVESTIGATION OF THE MODE OF COMMUTING TO SCHOOL OF STUDENTS IN THE EASTERN AGGLOMERATION OF BUDAPEST

\author{
Erdei Attila \\ PhD hallgató \\ Szent István Egyetem, Enyedi György Regionális Tudományok Doktori Iskola \\ E-mail: erdei1974attila@gmail.com
}

\section{Összefoglalás}

A mobilitás, mint a XXI. század társadalom alapvető szükséglete, a közösségi közlekedési rendszerek segítségével is megvalósítható. A versenyképesség, a megfelelő életminőség és a társadalmi összetartozás is ezzel biztosítható. Az utasok, a szolgáltatók, illetve a döntéshozó, hatósági szerepet betöltő szervezetek (pl. állam, önkormányzatok, szakhatóságok) napjaink közlekedési rendszereinek legfőbb szereplői. A vonalas infrastruktúrákkal való ellátottság jól jellemzi egy adott terület fejlettségét, gazdasági-társadalmi súlyát. Egy agglomerációs terület életében fontos tényezőt jelentenek az infrastruktúra igénybevételét befolyásoló tényezők (pl. a kiszolgálás sűrüsége, menetrendszerüsége, hozzáférhetősége, városhoz/városközponthoz való közelsége, késések, zsúfoltság stb. A vasúti és a helyiérdekű vasúti (HÉV) vonalakkal, mint a közösségi közlekedés legelterjedtebb, több mint másfél évszázados múltra visszatekintő képviselőivel, Budapest keleti agglomerációjában is találkozhatunk. A régió közlekedési térképén két fontos gerincet alkot a gödöllői HÉV-vonal és az azzal szinte hurkot képező 80a számú MÁV vasúti fővonal (Budapest-Hatvan). Tanulmányomban primer kérdőíves kutatás segítségével Budapest keleti agglomerációjában vizsgálom meg 11. osztályos középiskolások iskolába járási szokásait.

\begin{abstract}
Mobility, as the basic need in the 21 st century society can also be met with the help of public transport systems. This will also ensure competitiveness, an adequate quality of life and social cohesion. Passengers, service providers and decision-making organizations with an official role (e.g. the state, local governments, specialist authorities) are the main actors in today's transport systems. The provision of line infrastructures well characterizes the development and economic and social weight of a given area. An important factor in the life of an agglomeration is the factors influencing the use of infrastructure (e.g. density of service, schedule, accessibility, proximity to the city / city centre, delays, congestion, etc. The railway and local railway (HÉV) lines, as the most common representatives of public transport, dating back more than a century and a half, can also be found in the eastern agglomeration of Budapest. The Gödöllö HÉV line and the MÁV main railway line 80a (Budapest-Hatvan), which form an almost loop with it, form two important backbones on the transport map of the region. With the help of primary questionnaire research, I examine the schooling habits of 11th grade high school students in the eastern agglomeration of Budapest.
\end{abstract}

Kulcsszavak: helyiérdekü vasút, közlekedés, operátor, regionális vonalak, szállitás JEL besorolás: $R 41, R 11, R 12$

LCC: TF501-668, TF670-851, DB981-997, HE199.9 


\section{Bevezetés}

Az első magyarországi vasútvonal 1846-os átadása óta eltelt több mint 150 év alatt, a folyamatosan bővülő magyar vasúthálózat képes volt betölteni az iparosodó társadalom igényeit, közben mintegy motorját képezte a korabeli fejlődésnek. Az 1867-es kiegyezés egy békés, gyarapodó korszak kezdetét jelentette Magyarország számára. A kiegyezést követően az állam mind jelentősebb szerepet vállalt a vasúthálózat fejlesztésében, ehhez pedig felhatalmazást kért és kapott jelentős mértékü, a vasút fejlesztésére fordítható államkölcsön felvételére. Ez a jelentős pénzügyi keret tette lehetővé az állam számára, hogy felvásárolja a csődbe ment Cs. Kir. szabadalmazott Magyar Éjszaki Vasúttársaságot és az általa épített PestHatvan-Losonc-Selmecbánya vasútvonalat. A Közmunka- és Közlekedési Minisztérium 1869en úgy döntött, hogy az állami tulajdonba vett vasútvonal és a hamarosan átadandó ZákányZágráb vonal neve Magyar Királyi Államvasutak legyen. Ezt az évet tekintjük a MÁV (Magyar Államvasutak) alapítási évének, és a megvásárolt vonal lett a MÁV első vasútvonala.

A polgárosodás és az ipari termelés növekedésének hatására az ország egyre több városa vált regionális központtá. A XIX. század közepén megindult vasútépítési láz elérte a kisebbnagyobb regionális központokat is, ahol új törvényi szabályozás (1880. évi XXXI. törvénycikk) hatására a vállalkozó szellemü helyi nagybirtokosok és befektetők egyre több és több helyiérdekü vasutat kezdtek el építeni. A HÉV a helyiérdekü vasút kezdőbetüiböl összeálló mozaikszó. Sokan azt gondolják, hogy ez csak a budapesti helyiérdekü vasutakat foglalja magában. Általában ezek a vasutak olyan térségekben épültek, ahol a nagyvasúti vonalhálózat nem tárta fel az adott régiót. Ám nemcsak Budapest környékén, hanem szerte az országban épültek helyiérdekü vasutak a XIX. század második felétől az I. világháború végéig, létrehozva az ún. vicinálisok hálózatát (1. ábra).

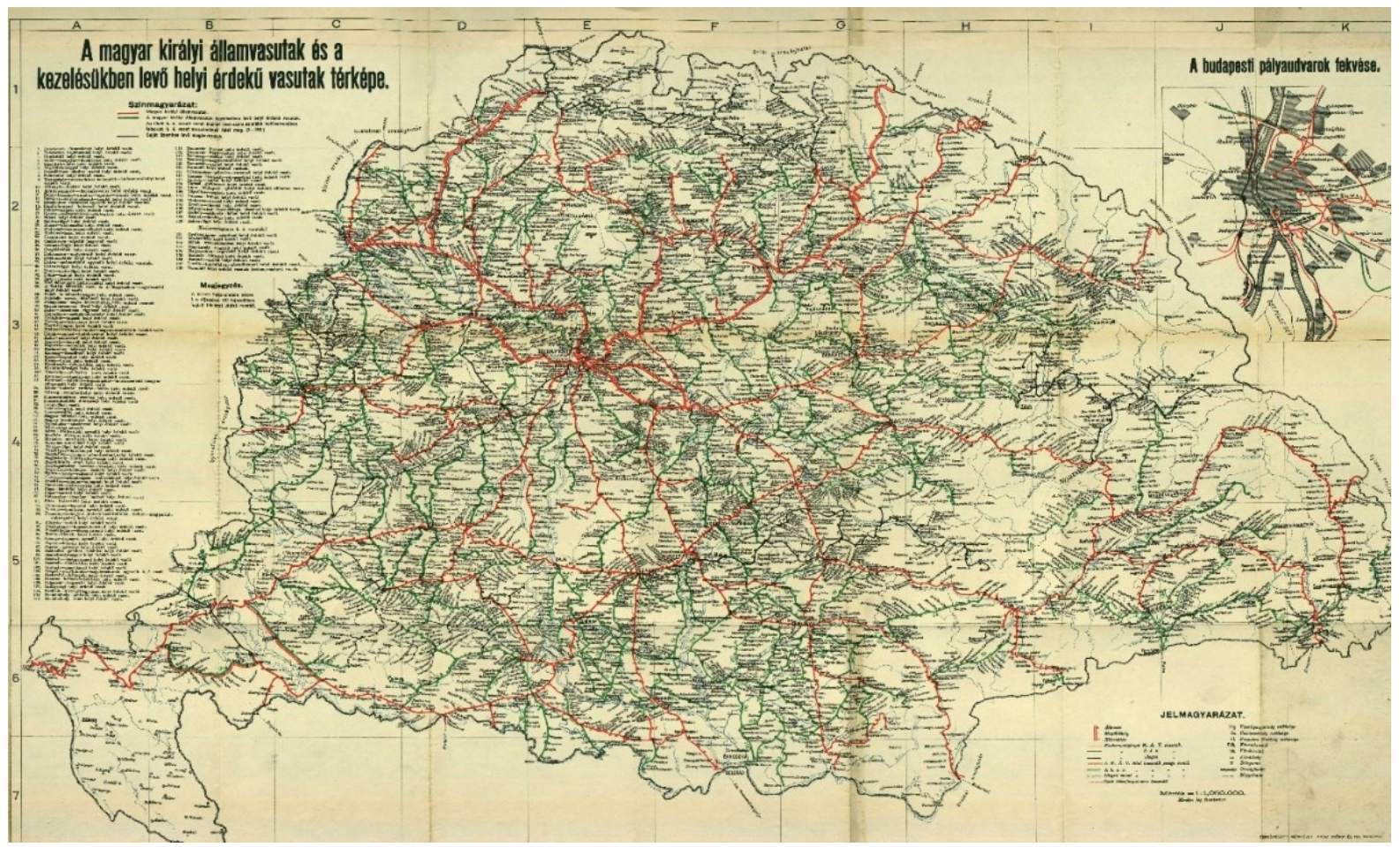

1. ábra: A magyar királyi államvasutak és a kezelésében levő helyiérdekü vasutak térképe 1914-ben

Forrás: $M A ́ V$ (2018) 
A térképen 138 helyiérdekü vasutat tüntettek fel, amelyböl 129 normál nyomtávú, 9 pedig ún. keskeny nyomtávú vonal volt. E vonalak nagy részéből alakult ki később a MÁV mellékvonali hálózata. Az 1918. évi 23 ezer kilométeres magyar vasúthálózat 57\%-a, 13 ezer kilométer volt a HÉV társaságok kezében (Wettstein - Szabó, 2005). Mint a névből is látszik, a HÉV-ek elsődleges célja a helyi érdekek kiszolgálása volt, például sokszor a helyi nagybirtokosok birtokain megtermelt termékek piacra juttatása.

A helyiérdekü vasutak építési láza az ország középpontjának és szívének számító Budapestet sem kerülte el, amelynek fejlődése ebben az időszakban robbanásszerü volt, a századfordulóra igazi metropolisszá vált a Kárpát-medence szívében. Hatalmas gyárai egyre távolabbi környékről vonzották a dolgozókat, míg újonnan felépült vásárcsarnokai és forgalmas piacai a környező települések gazdáinak, kofáinak nyújtottak megbízható jövedelemforrást.

A budapesti helyiérdekü vasutakra a főváros terjeszkedése, a személy- és áruszállítási igények növekedése miatt lett szükség. A föváros 1873-as egyesítését követően ugyanis rohamosan nőtt azok száma, akik Budapesten dolgoztak ugyan, de a környező települések olcsóbb telkein építkeztek és laktak. A fővárosban terebélyesedö közúti vasúthálózat mellett egyre inkább igénnyé vált a Budapesttől nem túl távoli községek bekapcsolása a helyi forgalomba, vagyis a HÉV gondolata is felmerült. A kivitelezés fő szempontja a takarékosság, a helyi anyagok, az eszközök, a tőke és a munkaerő bevonása, valamint a müködtetés kis forgalomhoz illeszkedő alacsony költségszintje volt (Tisza, 1996). Emellett megjelent egy új életforma, a turizmus is. A különböző HÉV vonalak ideális eszközei voltak a föváros körül elhelyezkedö, egyre népszerübb kirándulási és pihenési célpontok, mint például a Dunakanyar, a Gödöllői-dombság, a Csepel-sziget és Ráckeve környéki üdülök elérésének.

Az I. világháborút követő területi változások jelentős változást jelentettek, mivel a vonalhálózat jelentős része más országok területéhez került. A magyar vasúthálózat az európai fejlődéssel szinkronban jött létre és a II. világháború időszakáig folyamatosan lépést tudott tartani a müszaki fejlődéssel (hálózatsürüség, kétvágányú vonalak aránya, villamosított vonalak aránya, pályára engedélyezett sebesség, hézagnélküli felépítmény aránya, nagytömegü sínek aránya, állomások száma, szintbéli útátjárók, mütárgyak, biztosítóberendezés, jármüvek stb.).

Jelenleg a tömegközlekedés aránya nemzetközi összehasonlításban még kedvezőnek mondható, de a rendszerváltozást követő évtizedekben a társadalmi, gazdasági folyamatok, valamint a rendszeresen elmaradó infrastruktúrafejlesztés miatt a magyar vasút utasforgalma folyamatosan csökkent és folyamatos piacvesztés következett be. Még a relatív legsikeresebb Budapest elővárosi forgalomban is jelentős visszaesés következett be, mely megfigyelhető abban is, hogy a Budapest agglomerációjából a fövárosba ingázók alig 15\%-a veszi igénybe a vasút szolgáltatásait.

\section{Anyag és módszertan}

Tanulmányomban szekunder irodalmak felhasználásával ismertetem az olyan kötöttpályás közlekedési eszközök, mint a vasúti fővonalak és a HÉV-vonalak, létrejöttét Magyarországon.

Az agglomerációban élők életének mindennapos tevékenysége a napi ingázás. Ez a naponta ismétlődő vándorlási folyamat a lakosság jelentős részét érinti. Az agglomeráció társadalmi, gazdasági folyamatai és a közösségi közlekedési infrastruktúra egymással függő viszonyban állnak. A 345/2012. (XII.6.) Korm. rendelet alapján a Rákos-Hatvan-Miskolc-Nyíregyháza vasúti szakasz rekonstrukciója nemzetgazdasági szempontból kiemelt jelentőségü beruházások körébe tartozik. A munkálatokat több szakaszra bontva végzik el. A legnagyobb terjedelmü, a 
Pécel-Aszód pályaszakasz teljes felújítása 2018-tól 2019 decemberéig zajlott a vasúti forgalom teljes kizárásával Budapest keleti agglomerációjában. A kieső szerelvényeket az elővárosi forgalomban Pécel és Aszód között pótlóbuszokkal, illetve a H8-as Budapest-Gödöllő HÉV segítségével pótolták. Az Intercity forgalomban, Budapest-Hatvan viszonylatban közvetlen vonatpóló buszok közlekedtek. Az agglomeráció keleti területét kiszolgáló MÁV vasútvonalak felújítása hatással van a társadalomra, ezért primer kérdőíves kutatást készítettem 2019. májusban-júniusban, az agglomerációban élő, vagy tanuló (11. osztályos) középiskolás diákokkal iskolába járási szokásaikról, melynek eredményét tanulmányomban ismertetem. A vizsgálatba 6 középiskola 11. osztályos diákjai kerültek bevonásra, és a kérdőívet papír vagy elektronikus felületen (Google Drive) töltötték ki.

Vizsgálataim alapján a következő hipotéziseket állítottam fel:

H1: A megfelelö közösségi közlekedési infrastruktúra kialakítása (helyileg, sürüségben stb.) „pozitív irányban” befolyásolhatja a budapesti agglomeráció keleti területének egyes demográfiai mutatóit.

H2: A budapesti agglomeráció keleti területén élö és/vagy tanuló középiskolás tanulók számára a kötöttpályás közösségi közlekedés megfelelő kialakítása a mindennapjaik számára jelentős befolyással bír, a hálózatban keletkező zavar, a szolgáltatás megszünése, meghibásodása nagy problémát okoz a család életében.

\section{Eredmények}

Budapest agglomerációjának kialakulása egy időben hosszabb folyamat eredménye, fontos történelmi, városfejlödési, urbanizációs aspektusokkal. Enyedi György (1988) megfogalmazása szerint: „Az urbanizáció egy „kettős értelmü térbeli folyamat: a) a népesség állandó átrendeződése a településhálózaton belül és b) a „városi” technikai civilizáció, szokások, foglalkozások, fogyasztási és kulturális formák elterjedése az egész településhálózatban."

Tóth és Káposzta (2014) nagyon fontos megállapítása, hogy a területfejlesztés az egyik legfontosabb célja a területi politikának és a területi tervezésnek. Ebbe mind az urbanizáció, mind a településfejlődés beletartozik, nem elfelejtve természetesen az általános gazdasági fejlödést sem. A fejlesztés eszközeit Káposzta (2019) müvében is tetten érhetjük. Ezek közül véleményem szerint a régió erőforrásainak és a közszolgáltatásainak javítása tartozik a legfontosabban közé.

Budapest, mint Magyarország gazdasági, politikai központja mindig is vonzotta a munkát, boldogulást kereső emberek tömegeit. Ezek az emberek pedig szükségleteket generáltak, úgy, mint lakhatás, élelmezés, közlekedés. A fővárosba költöző tömeg között egyre több, egyre szegényebb ember érkezett, akik nem tudták a főváros ingatlan árait megfizetni, ezért a főváros környéki településeken vásároltak maguknak ingatlanokat, ahonnan naponta be tudtak járni a fövárosban levő munkahelyeikre.

Budapest (az 1872-es egyesítés előtt Pest, Buda és Óbuda) és környékének urbanizációs folyamatainak kezdete a XIX. század első felére tehető. 1950-ben jött létre az ún. „Nagy Budapest”, amikor 23 települést csatoltak a fővároshoz. A főváros agglomerációjának első hivatalos lehatárolása 1971-ben, az 1005/1971. (II.26.) számú kormányhatározattal történt meg, amely Budapesttel együtt 45 települést sorolt a főváros agglomerációjához. A lehatárolás a közlekedési és rekreációs kapcsolatok erősségén alapult. Már ekkor is figyelembe vették az ingázási viszonyok alakulását. A jelenlegi érvényes lehatárolás (Budapesti Agglomeráció Területrendezési Tervéröl szóló 2005. évi LXIV. törvény) szerint Budapest agglomerációja a 
fővárost és a körülötte elhelyezkedő 81 település által alkotott településgyürüt foglalja magába több mint 2,5 millió lakossal. Az agglomeráció valamennyi települése Pest megye területén helyezkedik el. Vizsgálataim során az agglomeráció keleti szektorában elhelyezkedő terület (Gödöllő és környékének) kötöttpályás közlekedésének változását, illetve ennek társadalmigazdasági hatásait vizsgálom (2. ábra).

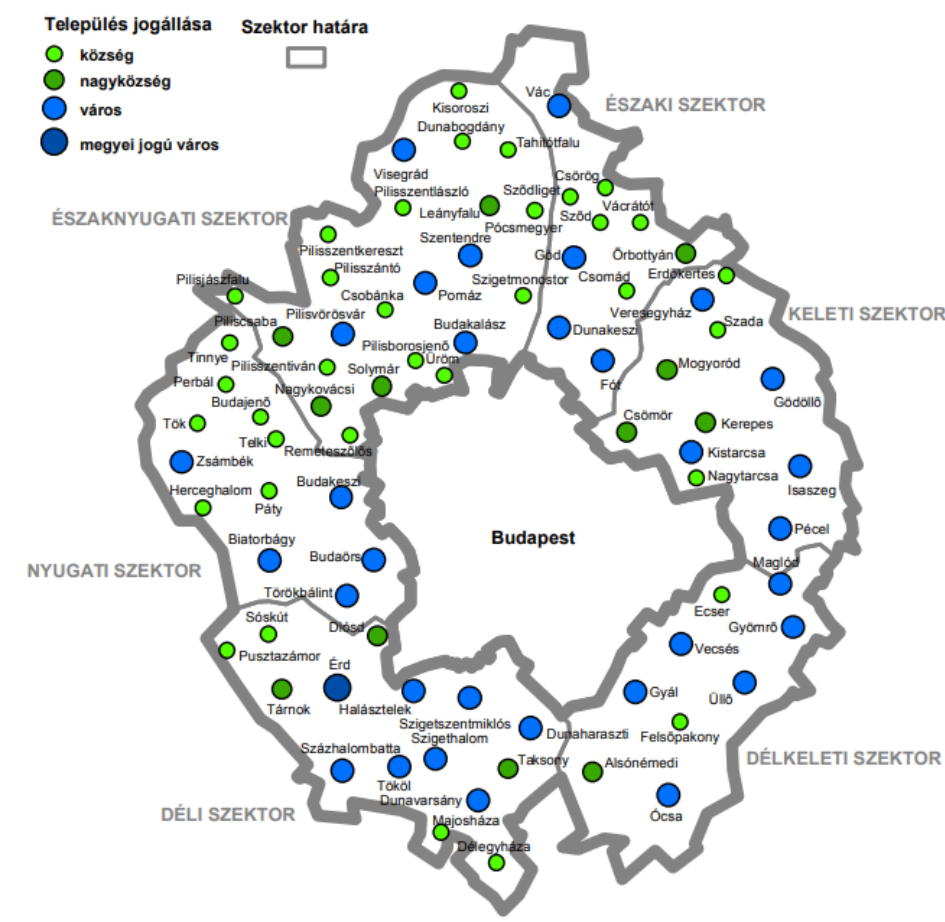

2. ábra: A budapesti agglomeráció szektorai, települései és azok jogállása

Forrás: KSH (2013)

A Gödöllői járás 15 települése (Csömör, Dány, Erdökertes, Gödöllő, Isaszeg, Kerepes, Kistarcsa, Mogyoród, Nagytarcsa, Pécel, Szada, Vácszentlászló, Valkó, Veresegyház, Zsámbok) közül a 2005. évi LXIV. törvény alapján 11 település (Csömör, Erdőkertes, Gödöllő, Isaszeg, Kerepes, Kistarcsa, Mogyoród, Nagytarcsa, Pécel, Szada, Veresegyház) alkotja Budapest agglomerációjának keleti szektorát. A felsorolt települések összterülete $317 \mathrm{~km} 2$, lakosságának száma a 2015-ös mikrocenzus adatai alapján 133.748 fő.

A vizsgált települések között 2 község, 3 nagyközség és 6 város található. A 6 város közül legrégebben, 1966-ban, a korábban mezővárosi címet birtokló Gödöllő nyerte el a városi címet. A KSH (2019) adatai alapján Gödöllö lakosságának száma 1990 és 2019 között 18\%-kal nőtt, 2019-ben elérte a 32.099 föt. A járás második legnagyobb és egyben legdinamikusabban fejlödő városa, Veresegyház, amely 1999-ben nyerte el a város címet. A település a rendszerváltás óta eltelt 30 év alatt megháromszorozta lakosságszámát (1990: 6.120 fö, 2019: 19.275 fö). Az agglomeráció keleti szektorának harmadik legnagyobb városa Pécel, amely 1996 óta város. Lakossága 1990 és 2019 között 10.571 forröl 16.310 före, több mint 50\%-kal növekedett.

Az új évezredben három település is városi jogot kapott a vizsgált területen. 2005-ben Kistarcsa kezdte a sort, amely szintén jelentős (1990: 8.776 fó, 2019: 13.041 fö), 48\%-os népességnövekedést ért el. Majd Isaszeg 2008-ban kapta meg a város címet, melynek az elmúlt közel 30 évben kb. 30\%-kal növekedett lakosságának összlétszáma (1990: 8.907 fö, 2019: 11.513 fö). Továbbá a 2. ábrán még nagyközségként jelölt Kerepes 2013-ban kapta meg a városi 
címet. A település a terület városai között a második legnagyobb (65\%) lakosságszám növekedést érte el 1990 és 2019 között. Megjegyzem, a vizsgált területen az említett Veresegyház után a legnagyobb lakosságnövekedést elérő település 3 nagyközség és 2 község volt. Mind az öt település népességszáma legalább megduplázódott az elmúlt közel 30 évben.

Az adatok könnyebb feldolgozása érdekében a továbbiakban egyszerüsítésként a Gödöllöi járás demográfiai, társadalmi mérőszámait vettem figyelembe vizsgálataim során. A demográfiai adatok alapján megállapítható, hogy a vizsgált terület lakossága 1870 és 2019 között hétszeresére nőtt (3. ábra). Jelenleg e járás Pest megye legnépesebb járása.

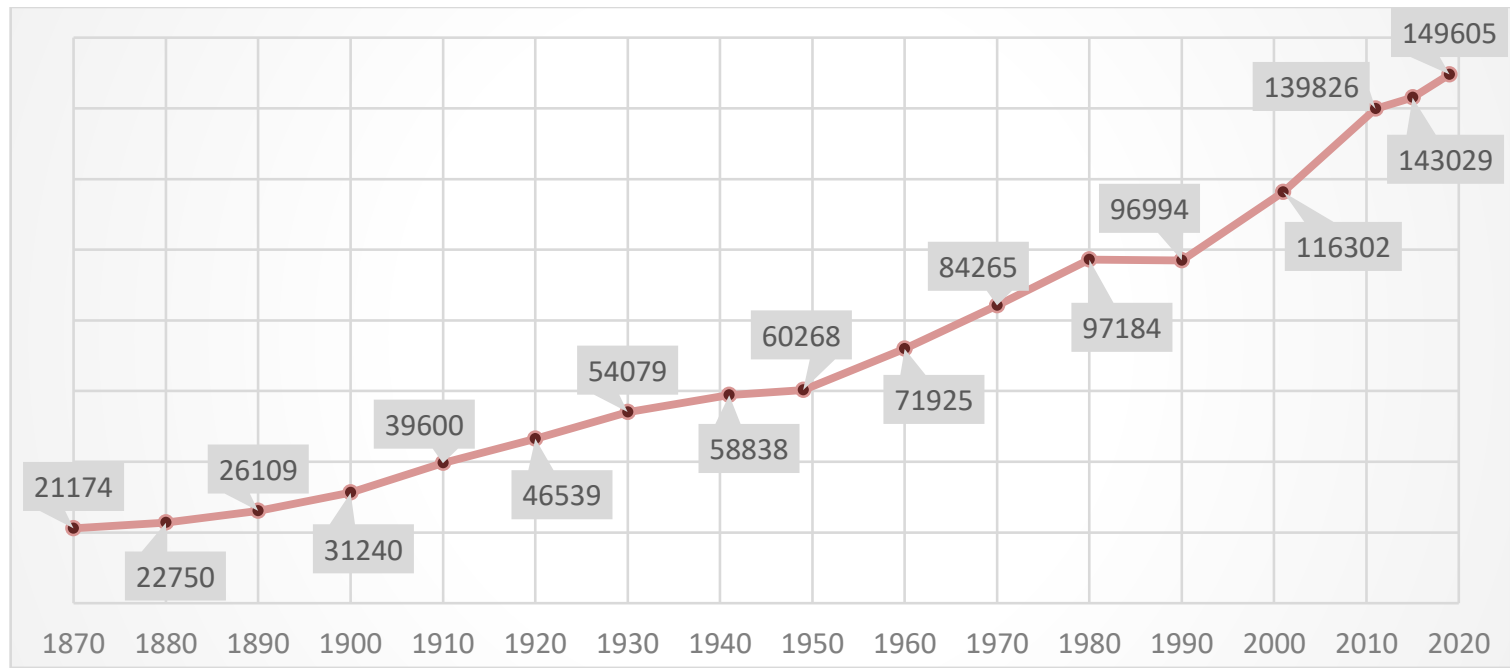

3. ábra: Gödöllői járás lakosságszámának alakulása (fö) (1870-2019)

Forrás: KSH (2019) adatai alapján saját szerkesztés

A Gödöllöi járás vándorlási egyenlege (9,13 ezrelék) is a 10 legmagasabb közé esik a Pest megyei járások között (4. ábra). Egy másik, hasonlóan sokat mondó mutató, az új építésü lakások aránya, és a legjobb tíz között szerepelt a Gödöllői járás 2015-ben (0,32\%-kal nőtt).

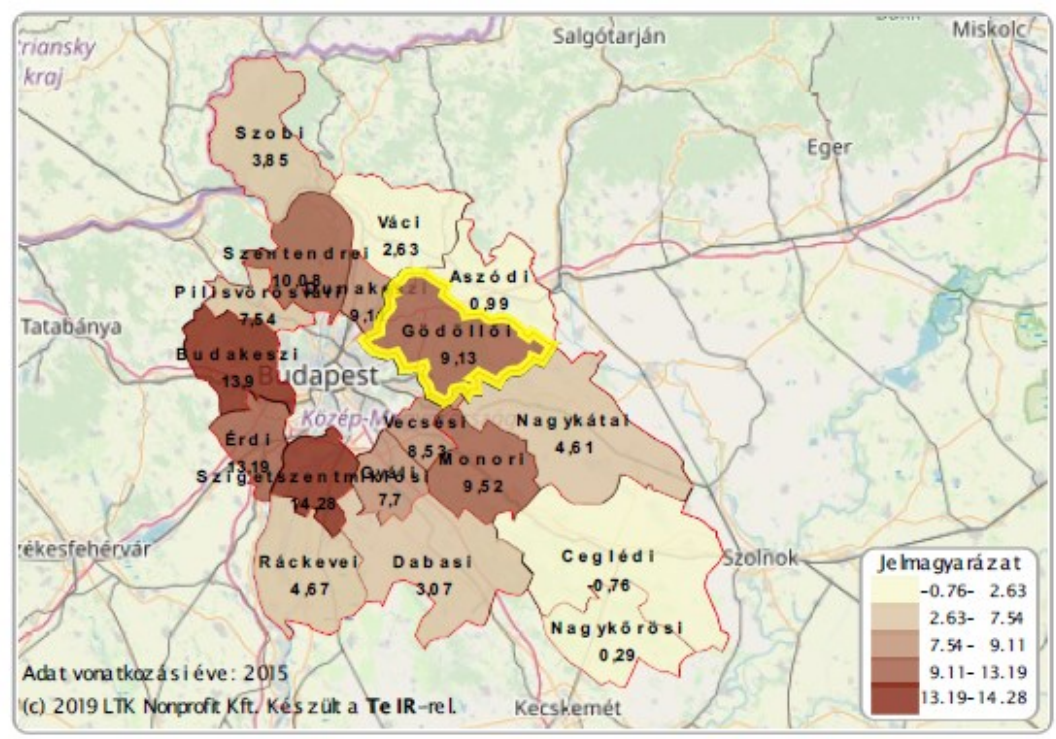

4. ábra: Vándorlási egyenleg Pest megye járásaiban (ezrelék)

Forrás: TeIR (2019) 
A gazdasági adatok vizsgálata alapján is elmondható, hogy vizsgált, Gödöllői járás az egyik legdinamikusabban fejlődő területe Budapest agglomerációjának, ahogy már Péli és Neszmélyi (2015) kutatása is rávilágított erre. A rendelkezésre álló mutatókat megvizsgálva több adat is világosan megmutatja, hogy milyen intenzív fejlődésen megy keresztül ez a járás. Az egyik ilyen mutató, az egy lakosra jutó összes nettó jövedelem alapján Pest megyén belül is előkelő helyet foglal el, ahogy ezt az 5. ábra is mutatja. A járási adatokat elemezve a Gödöllői járás az 5. helyet foglalja el a megye járásai közül 954.114 Ft egy lakosra jutó nettó jövedelem tekintetében.

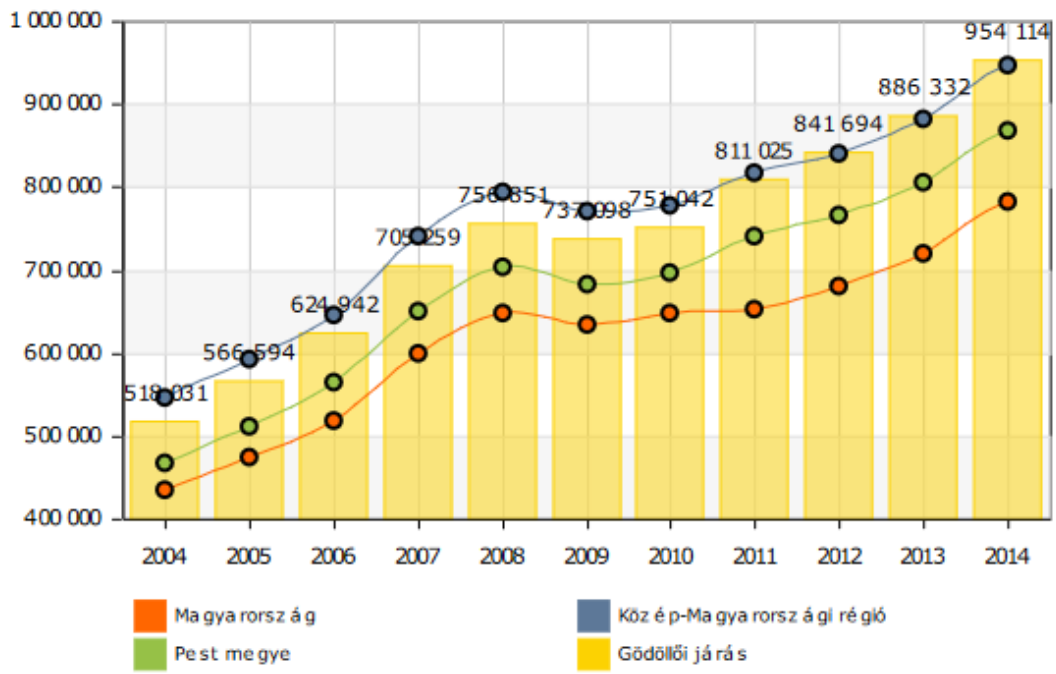

5. ábra: Egy lakosra jutó összes nettó jövedelem Pest megye járásaiban (Ft) Forrás: TeIR (2019)

\section{Agglomerációs ingázás}

Az agglomerációban élők számára Budapest hatalmas munkaerő-piaci szívóhatást hoz létre, amely azonban nemcsak a régióban élő munkavállalókat hozza mozgásba, hanem azon jóval túlnyúlva is kifejti erejét. Budapest szerepe kiemelkedő a szomszédos területen élök foglalkoztatásában, de elmondható az is, hogy a főváros lakosainak egy része viszont az agglomerációban vállal munkát. A fővárosban és agglomerációjában a 2011-es népszámlálás adatai szerint a foglalkoztatottak közel negyede más településre járt dolgozni, mint ahol a lakhelye volt.

A KSH (2014) statisztikai adataiból megállapítható , hogy az agglomerációs gyürü településein 64\% volt az ingázók aránya, akik közül majdnem minden második (összesen 143 ezer fö) Budapesten vállalt munkát (ez az oda bejáróknak közel kétharmadát teszik ki). A fövárosban élö foglalkoztatottak között 2011-ben 10\% (kb. 79 ezer fö) volt a más településre járó dolgozók száma. Az ingázó budapesti munkavállalók közel felének az agglomerációs övezet településeinek valamelyikén volt a munkahelye.

Az agglomeráció településeiről a fövárost többféle közösségi közlekedési eszközzel lehet elérni. A főváros szűkebben vett vonzáskörzetének településeinek döntő többsége átszállás nélkül közvetlenül elérhető helyközi buszjáratokkal, vagy BKV (Budapesti Közlekedési Vállalat) járatokkal. A kötöttpályás közlekedési mód igénybevételével az agglomeráció településeinek több mint 50\%-a átszállás nélkül elérhető. Megjegyzendő azonban, hogy míg a helyközi buszjáratok a települések belső útvonalait is szinte minden esetben feltárják, addig a vasúti összeköttetésnél sok esetben a településcentrumától távolabb, akár a közigazgatási 
határon kívül is elhelyezkedhetnek az állomások, megállóhelyek, megnövelve ezzel az eljutás idejét.

Budapest agglomerációjának közlekedési térképét tanulmányozva látható, hogy a vizsgált keleti agglomerációs területet (Gödöllői járás) az alábbi kötöttpályás vonalak érintik (6. ábra):

- Gödöllői HÉV (H8) a MÁV-HÉV kezelésében (1888-tól),

- MÁV 80a számú, 2 vágányú, villamosított fővonala (Budapest-Hatvan),

- MÁV 71 számú fővvonala Budapest-Veresegyház-Vácrátót-Vác (1911-től),

- MÁV 72 számú 1 vágányú mellékvonala (Vác-Veresegyház-Gödöllö) (1911-1970-ig).

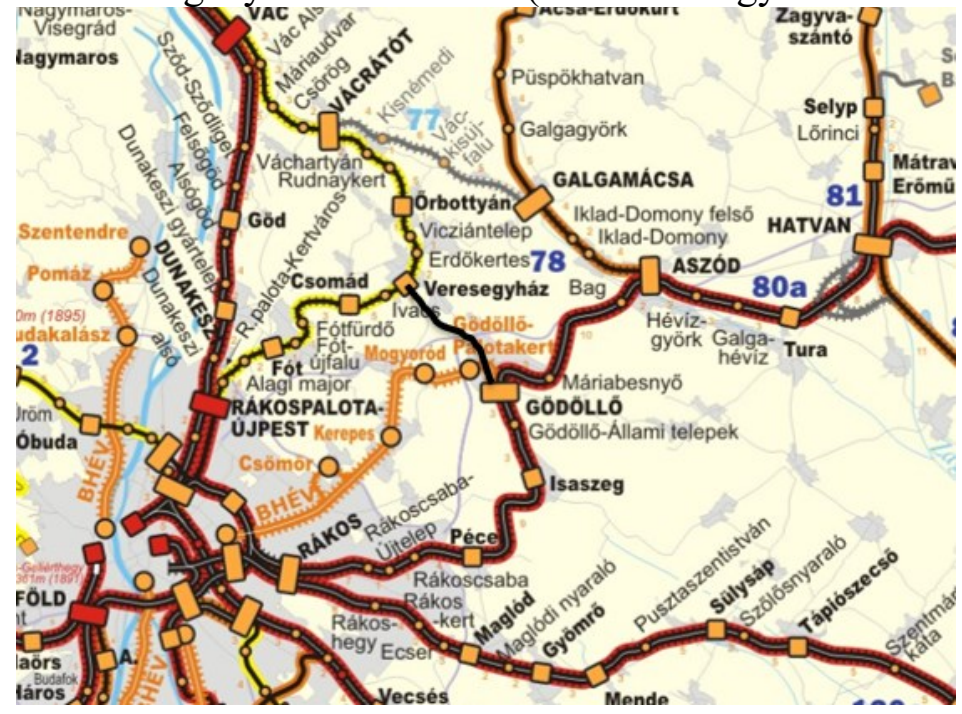

6. ábra: Budapest keleti agglomerációjának kötöttpályás közlekedési hálózata Forrás: $M A ́ V$ (2016)

A MÁV 72 számú 1 vágányú mellékvonalát 1970-ben a közúti lobbi és gazdasági megfontolások hatására bezárásra ítélték. A vasúti pályát felbontották, sajnos ma már csak ittott lehet egy-egy nyomát megtalálni. A döntés helyessége napjainkban kérdőjelezhető meg igazán, amikor a terület demográfiai, gazdasági növekedésének hatására a közúti közlekedés elviselhetetlen mértéket öltött, állandósultak a dugók, a környezetterhelés szinte elviselhetetlen szintet ért el. Erdei és Erdeiné Késmárki-Gally (2018) tanulmánya szerint a világ más tájain, pl. Kínában ezekkel a visszafejlesztési tendenciákkal szemben a vasút reneszánszát éli, sorra épülnek az új, nagy sebességü vasútvonalak.

\section{Primer kérdő́ves kutatás középiskolás (11. osztályos) tanulók körében}

A Gödöllői járásban végzett kutatás célja a középiskolások iskolába járásra vonatkozó preferenciáinak felmérése, különös tekintettel a tanulók iskolába járási közlekedési szokásainak részletes feltérképezése a vasútvonal felújításának figyelembevételével. A kutatás célcsoportja a felújítás alatt álló 80a vasútvonal mentén elhelyezkedő településeken (Gödöllő, Isaszeg, Pécel) található középfokú tanintézményekben tanuló 11. osztályos középiskolások. A vizsgált települések elhelyezkedésük miatt is mind kiinduló pontjai, mind célpontjai a tanulók ingázásának. A nemzeti köznevelésröl szóló 2011. évi CXC. törvény 7.§-a szerint a középiskolai oktatás szervezeti keretei a gimnázium, a szakgimnázium és a szakközépiskola. A vizsgált három település gimnáziumai, szakgimnáziumai, szakközépiskolái vonzó célpontot nyújtanak a környező kisebb települések (de még a föváros) középiskolás korú diákjai számára. Gödöllön $5 \mathrm{db}$, Pécelen $2 \mathrm{db}$, Isaszegen $1 \mathrm{db}$ középiskola található, melyből a kutatásba $6 \mathrm{db}$ középiskola került bevonásra. 
A középiskolai oktatás hagyományosan a 9. évfolyamon kezdődik és a 12. évfolyamig tart. A vizsgált célcsoport a 11. osztályos középiskolások azért, mert a vizsgálati időszakban (2019. május 15. és 2019. június 12. között) a 12. évfolyam tanulói az érettségi időszak miatt nem voltak elérhetőek, a 9. és 10. évfolyam diákjai pedig nem rendelkeztek a korábbi időszakra vonatkozó tapasztalatokkal, amelyek fontosak a kérdőív egyes pontjainál.

A kérdőíves kutatás összesen 21 db kérdést tartalmazott. A kérdőív 2019 tavaszi próbakitöltéseket követően került véglegesítésre. A kérdőív több kérdéscsoportot, nyitott és zárt kérdéseket egyaránt tartalmazott. A kérdőív két fő részből állt. Az első részt (1-15. kérdés) minden tanuló kitöltötte, a második részt (16-21. kérdés) azok a diákok, akik az iskolába járás során igénybe vették a felújítás alatt álló $80 \mathrm{a}$ vasútvonalat, illetve a felújítási időszakban közlekedő vonatpótló járatokat. Az első rész első kérdéscsoportja (1-5. kérdés) a diákok alapadataira vonatkozott (évfolyam, nem, állandó lakóhely, iskola megnevezése). Az évfolyam meghatározása a rosszul célzott kitöltések (pl. nem 11. osztályos tanuló) kizárására szolgált. A második kérdéscsoport 6-11. kérdés) az iskolába való bejárásra vonatkozó kérdéseket tartalmazott (átlagos eljutási idő, közlekedési mód, eszköz, választás oka, átszállás szükségessége, iskolaválasztás megközelíthetőségi szempontja). A harmadik kérdéscsoport (12-15. kérdés) a tanulók által használt két legjellemzőbb közlekedési eszközre fókuszált (negatív és pozitív jellemzők, a közösségi közlekedési szolgáltatás kiesésének megoldása az iskolába való bejutáshoz). A kérdőív második részének első kérdéscsoportja (16-18. kérdés) a vasútvonal felújítása során tapasztalt nehézségekre vonatkozott. A második kérdéscsoport (1921. kérdés) a jövőbeni elvárásokat és a várható utazási szándékokat tartalmazta.

A beérkezett értékelhető összes elemszám n=526 fő volt. A kitöltők 41\%-a fiú ( 217 fö) és 59\%a lány (309 fö).

A diákok ingázási eredménye megközelíti a 2011-es statisztika agglomerációs ingázásra vonatkozó adatokat. A megkérdezett tanulók között az ingázók aránya közel 70\% (7. ábra). A Budapesten élök és onnan ingázók aránya a teljes sokaság 12\%-a volt, ami szintén közel azonos a 2011-es a munkaképes korú ingázók arányaira vonatkozó statisztikai adatokkal.

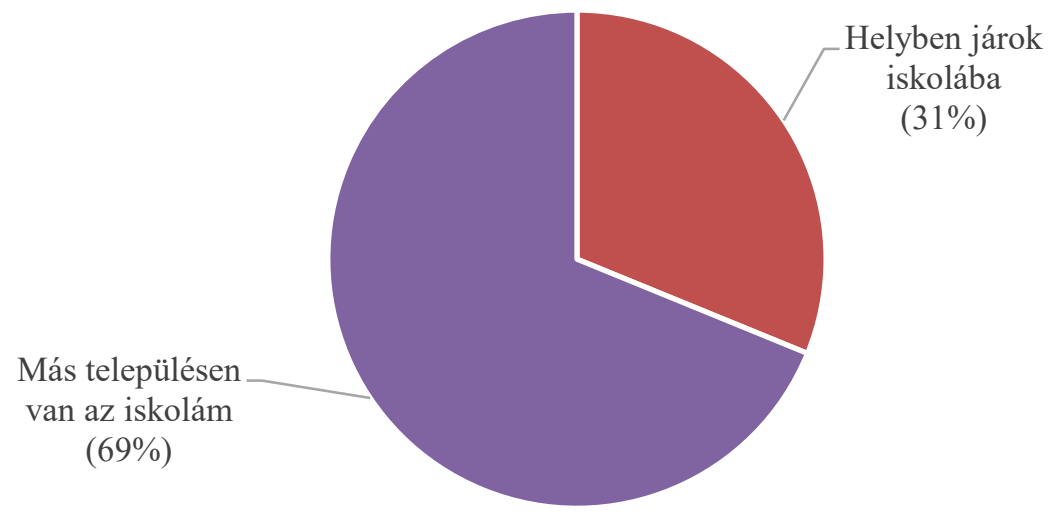

7. ábra: A kérdőívet kitöltők ingázási aránya (n=526 fö)

Forrás: Saját kutatás alapján

A tanulók iskolába járási szokásainak vizsgálata során a kitöltők életkora miatt (17-18 évesek) várható volt, hogy kisebb mértékü lesz az autóval történő ingázás, mint a dolgozók között. A tanulók jellemzően a távolsági/helyközi autóbusszal való bejárást választják (41\%), illetve a 
gyalogos közlekedést (19\%), amely a helyben lakók aránya miatt indokoltnak tekinthető (8. ábra).

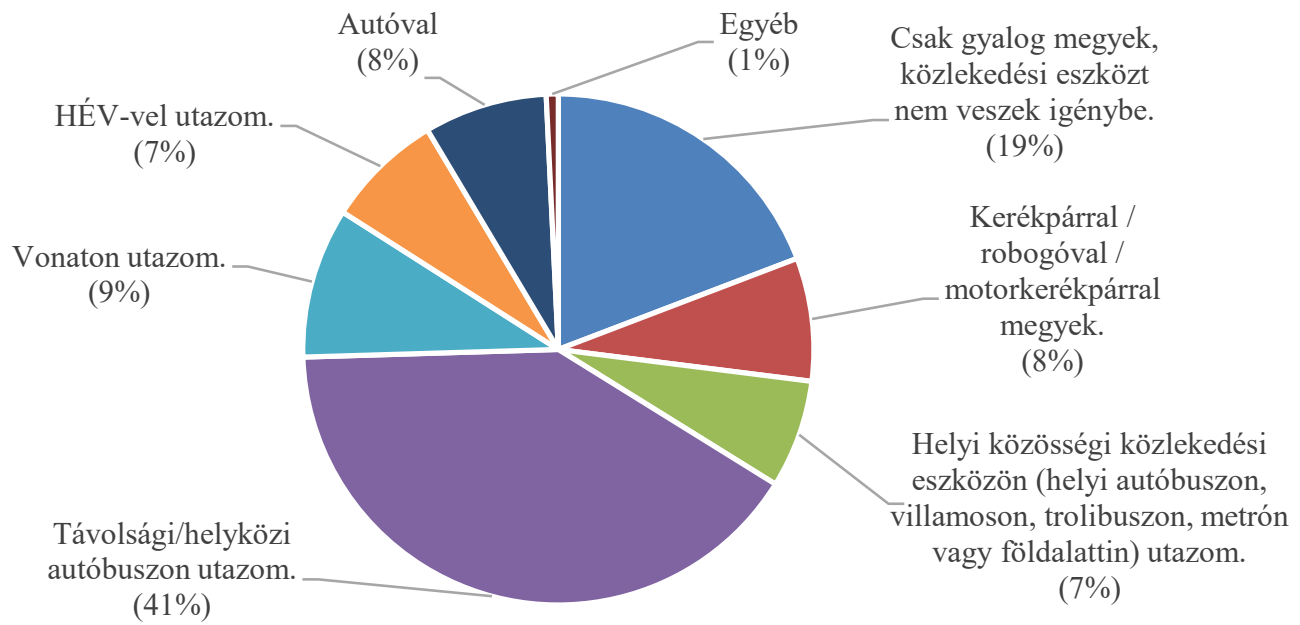

8. ábra: A kérdőívet kitöltők reggel iskolába járási szokásainak megoszlása $(\mathrm{n}=526$ fö) Forrás: Saját kutatás alapján

Az 526 válaszadóból 339 fö (64\%) veszi igénybe naponta a közösségi közlekedési módokat (busz, helyi közlekedés, HÉV, vonat) az iskolába járáshoz, melyböl a kötöttpályás közlekedés (HÉV, vonat) részaránya $16 \%$.

A kutatásban a közösségi közlekedési eszközt használó válaszadók elégedettségét is felmértem. Azon diákok válaszát vettem figyelembe, akik közösségi közlekedési eszközt vettek igénybe a reggeli iskolába járáshoz (vonat, HÉV, távolsági/helyközi busz, helyi közlekedés). Ebben az esetben az elemzésbe bevont elemszám 339 fő volt (nkk=339fö).

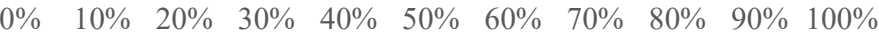

Csatlakozási és átszállási lehetőségek

Járatsürüség, gyakoriság

Járművek korszerüsége, utaskényelme

Járművek tisztasága

Megállók elhelyezkedése, úticéltól való távolsága

Megállók tisztasága

Megbízhatóság, pontosság

Utastájékoztatás, információellátottság

Utazási (menet)idő az úticélig

Zsúfoltság

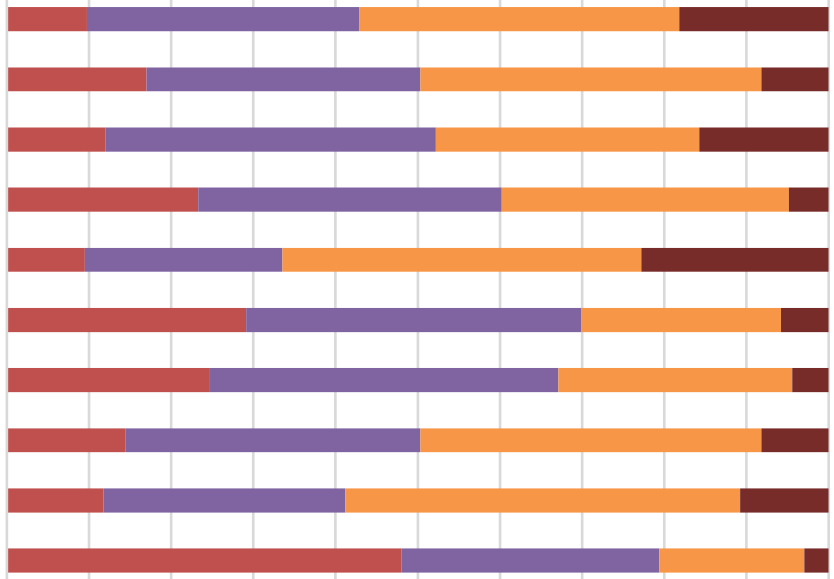

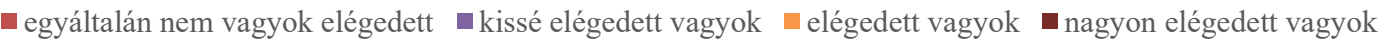

\section{9. ábra: A közösségi közlekedést használók elégedettsége az igénybe vett szolgáltatással (nkk=339 fó)}

Forrás: Saját kutatás alapján 
A 9. ábrán látható, a diákok leginkább a zsúfoltsággal, a megbízhatósággal, a megállók és járművek tisztaságával voltak elégedetlenek. Különösen kiemelkedő negatív vélemény a zsúfoltság tényező, ahol a két alsó kategóriában (egyáltalán nem vagyok elégedett, kissé elégedett) összesen közel 80\%-os értéket kaptam. A tanulók leginkább a megállók elhelyezkedésével, az utazási (menet)idővel és a csatlakozási lehetőségekkel elégedettek. A legmagasabb értéket a két felső kategória (elégedett, nagyon elégedett) összesítésében a megállók elhelyezkedése mutatónál találtam. Az utastájékoztatás, a jármüvek utaskényelme és a járatsürüség esetén a pozitív és a negatív vélemények körülbelül azonos mértékben vannak jelen.

Ezt követően tovább szükítettem a vizsgált elemek számát, ugyanis azon tanulók véleményét vizsgáltam, akik a kötöttpályás közösségi közlekedést (vasút, HÉV) veszik igénybe a reggeli iskolába járáshoz. Az így kapott elemszám 89 fő volt (nvh=89fó).

A 10. ábrán megfigyelhető, a kötöttpályás közlekedést használó diákok az utastájékoztatással, a megállók tisztaságával, a járművek tisztaságával és a zsúfoltsággal elégedetlenek. A két alsó kategória (egyáltalán nem vagyok elégedett, kissé elégedett) mértéke megközelítette a 70\%-ot a megállók és a járművek tisztasága esetében. A kötöttpályás közlekedést használó tanulók leginkább a megállók elhelyezkedésével, az utazási (menet)idővel, a járatsürüséggel és a csatlakozási lehetőségekkel elégedettek. A járművek utaskényelme és a megbízhatósága/pontossága esetén a pozitív és a negatív vélemények körülbelül azonos mértékben jelennek meg.

Csatlakozási és átszállási lehetőségek

Járatsürüség, gyakoriság

Járművek korszerüsége, utaskényelme

Járművek tisztasága

Megállók elhelyezkedése, úticéltól való távolsága

Megállók tisztasága

Megbízhatóság, pontosság

Utastájékoztatás, információellátottság

Utazási (menet)idő az úticélig

Zsúfoltság
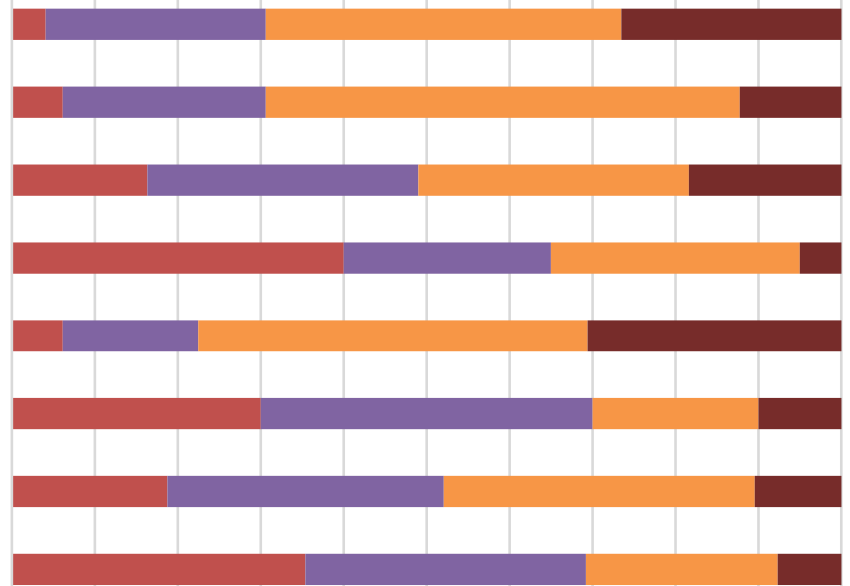

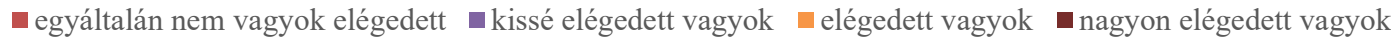

\section{0. ábra: A kötöttpályás közösségi közlekedést (HÉV, vasút) használók elégedettsége a} Forrás: Saját kutatás alapján 


\section{Következtetések}

Az agglomerációban élők életének mindennapos tevékenysége a napi ingázás. Ez a naponta ismétlődő vándorlási folyamat a lakosság jelentős részét érinti. Az agglomeráció társadalmi, gazdasági folyamatai és a közösségi közlekedési infrastruktúra egymással függő viszonyban állnak. Az infrastruktúra fejlesztése komplex módon befolyásolja a régióban élő emberek mindennapi életét.

Megállapítható, hogy a budapesti agglomeráció keleti területén kiépült kötöttpályás közlekedési infrastruktúra a régióra fontos hatást gyakorol.

A Gödöllői járás 3 településén (Gödöllő, Isaszeg, Pécel) élő és/vagy tanuló 11. osztályos diákok iskolába járási szokásait vizsgálva megállapítható, hogy a diákok ingázási szokásai jelentős mértékben megközelítik a 2011-es népszámlálás során kapott a statisztikai adatokat. A 3 vizsgált település középiskoláiba más településről az ingázók aránya közel 70\%-ot tesz ki.

A kutatási eredmények alapján elmondható, hogy a közösségi közlekedés meghatározó szerepet játszik a tanulók életében. A közösségi közlekedést igénybe vevő diákok „kritikus” szemmel tekintenek az igénybe vett szolgáltatásokra, elégedettségüket nagyban befolyásolják az infrastrukturális- és jármüfejlesztések. Mind a közösségi közlekedést használók, mind ezen belül a kötöttpályás közösségi közlekedést használók egyrészt a zsúfoltsággal, a megállók és jármüvek tisztaságával voltak leginkább elégedetlenek, másrészt a megállók elhelyezkedésével, az utazási (menet)idővel és a csatlakozási lehetőségekkel a legelégedettebbek.

\section{Irodalomjegyzék}

1. Enyedi Gy. (1988): A városnövekedés szakaszai. Budapest, Akadémiai Kiadó. 110 p.

2. Erdei A. - Erdeiné Késmárki-Gally Sz. (2018): Development of China's railway connections in the 21th century In: Neszmélyi, György Iván (szerk.) Regional integration and spatial processes in the world, Szent István Egyetemi Kiadó, Gödöllő, pp. 27-41.

3. Káposzta J. (2019): A regionális térszerkezet változásainak kapcsolatrendszere, STUDIA MUNDI - ECONOMICA 6: 3 pp. 18-28. DOI: 10.18531/Studia.Mundi.2019.06.03.18-28

4. KSH (2013): Közlemények a budapesti agglomerációról 16. https://www.ksh.hu/docs/hun/xftp/idoszaki/regiok/bptelepulesszerk.pdf (Hozzáférés: 2020. 04. 07.)

5. KSH (2014): Magyarország településhálózata 1. Agglomerációk, településegyüttesek. http://www.ksh.hu/docs/hun/xftp/idoszaki/mo_telepuleshalozata/agglomeracio.pdf (Hozzáférés: 2020. 04. 07.)

6. KSH (2018): https://www.ksh.hu/docs/teruletiatlasz/jarasok (Hozzáférés: 2020. 04. 07.)

7. MÁV (2016): Belső anyag.

8. MÁV (2018): Vasútállomások. A magyar királyi államvasutak és a kezelésében levő helyiérdekü vasutak térképe, http://vasutallomasok.hu/terk/MAVterkep.jpg (Hozzáférés: 2019. 01. 03.)

9. Péli L. - Neszmélyi Gy. I. (2015): Territorial Differences of Rural Cities and the Development of Transport Infrastructure in Hungary, ROMANIAN REVIEW OF REGIONAL STUDIES: JOURNAL OF THE CENTRE FOR REGIONAL GEOGRAPHY 11: (2) pp. 69-84. 
10. TeIR (2019): Gödöllői járás, Helyzet-Tér-Kép. http://www.teir.hu/helyzet-terkep/kivalasztott-mutatok.html (Hozzáférés: 2019. 02. 26.)

11. Tisza I. (1996): A magyar állami, magán- és helyiérdekű vasúttársaságok fejlődése 1876-1900 között, In: Kovács L. (szerk.): Magyar Vasúttörténet 2. kötet. Budapest: Közlekedési Dokumentációs Kft., pp. 83-84.

12. Tóth, T. - Káposzta, J. (szerk.) (2014): Tervezési módszerek és eljárások a vidékfejlesztésben (elmélet). Gödöllő: Szent István Egyetemi Kiadó, 2014. 163 p.

13. Wettstein D. - Szabó A. (2005): Helyiérdekü vasutak építészete. Architectura Hungariae

http//ww.arch.et.bme.hu/arch_old/korabbi_folyam/27/27szabow.html (Hozzáférés: 2019. 01.03.)

14. 1005/1971. (II.26.) számú kormányhatározat

15. 1880. évi XXXI. törvénycikk a helyi érdekü vasutakról

16. 2005. évi LXIV. törvény a Budapesti Agglomeráció Területrendezési Tervéről

17. 2011. évi CXC. törvény a nemzeti köznevelésröl

18. 345/2012. (XII.6.) Korm. rendelet egyes közlekedésfejlesztési projektekkel összefüggő közigazgatósági hatósági ügyek nemzetgazdasági szempontból kiemelt jelentőségü üggyé nyilvántartásáról és az eljáró hatóságok kijelöléséről 